
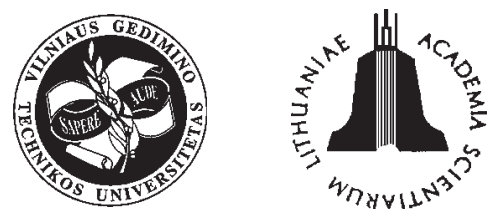

JOURNAL OF CIVIL ENGINEERING AND MANAGEMENT

http:/www.jcem.vgtu.lt

2005, Vol XI, No 2, 109-114

\title{
EVALUATION OF CONCRETE RESISTANCE TO CHLORIDE IONS PENETRATION BY MEANS OF ELECTRIC RESISTIVITY MONITORING
}

\author{
Marta Kosior-Kazberuk, Walery Jezierski \\ Białystok Technical University, Wiejska 45 E, 15-351 Białystok, Poland. \\ E-mail:m.kosior@pb.bialystok.pl,wizer@cksr.ac.bialystok.pl
}

Received 22 Dec 2004; accepted 15 Apr 2005

\begin{abstract}
The chloride-induced corrosion of reinforcing steel is the major reason for the premature deterioration and degradation of field concrete structures built in a salt-laden environment. The results of investigation of the bituminous addition effect on Portland cement concrete resistance to chloride ions penetration are presented in this paper. Chloride penetration was simulated by subjecting samples to cyclic loading with salt solution and drying. Concrete resistivity development was monitored during 12 months. The test results have been analysed to verify the effect of addition content, the time of exposure in aggressive environment, as well as the sort of cement on chloride ion permeability of Portland cement concrete. The statistical analysis showed that bituminous addition significantly improves the concrete resistance to chloride salt solution penetration.
\end{abstract}

Keywords: concrete, chloride ions, bituminous addition, electric resistivity, material and structural protection, cyclic wetting and drying, statistical analysis.

\section{Introduction}

The ingress of chloride ions into concrete plays a crucial role in reinforcing bar corrosion and, hence, in durability and life of structures. Chloride permeability of concrete is such an intrinsic property that needs to be assessed independently, especially in the design and construction of structures to be built in a salt-laden environment.

The main sources of chlorides in concrete are chloride ions ingressing from outside. In case of high-way structures and bridges, this can be caused by de-icing salts. Another source of chloride ions is sea water in contact with concrete. Chlorides may be also deposited on the surface of concrete in the form of very fine airborne drops of sea water, carried by wind. Brackish ground-water in contact with concrete is also a source of chlorides [1].

Chlorides penetrate concrete by diffusion of the ions in the water, as well as by capillary suction and by absorption. Prolonged or repeated ingress can, in time, result in a high concentration of chloride ions at the surface of reinforcing steel [2].

It is apparent that the progressive ingress of salts towards the reinforcing steel takes place under alternating wetting and drying. The transport of chlorides in concrete is influenced strongly by the exact sequence of wetting and drying. This sequence varies from location to location, depending on the wind, exposure to the sun and the shape and usage of the construction. Thus, different parts of the structure may undergo a different pattern of wetting and drying.

The modification of concrete, during mix preparation, with bituminous admixtures or additions may be an effective method of cement mortar and concrete protection against external environmental influence. The introduction of bituminous additions leads to the formation of hydrophobic coating on the walls of pores, to blocking the connections among them, to diminish the fraction of capillary pores in total porosity and to limit chlorides and other agents penetration into the concrete [3, 4]. The hardened cement stays the binder of material.

Concrete resistivity is a geometry-independent material property that describes the electrical resistance, that is the ratio between applied voltage and resulting current in a unit cell $[5,6]$. The resistivity of concrete may vary from $10^{1}$ to $10^{5} \Omega \mathrm{m}$, depending on the moisture content and the concrete composition. The current is carried by ions in the pore liquid. An increased pore saturation as well as an increased number of larger diameter pores (higher water-to-cement ratio) decrease resistivity. For constant moisture content, the resistivity increases with time (hydration). Resistivity also increases when the concrete dries out and when it carbonates, particularly in Portland cement.

In theoretical and experimental work there appears to be a correlation between concrete resistivity and chlo- 
ride ingress [5]. In general, the chloride diffusion coefficient is inversely proportional to the concrete resistivity. Within a particular structure, more permeable zones will have a comparatively lower resistivity and higher chloride penetration. The resistivity of concrete and the corrosion rate of reinforcement after depassivation are related. Ion transport between anodes and cathodes on the steel surface is one of the rate controlling factors.

The present investigation was carried out with an objective to assess the concrete modified by bituminous addition resistance to chloride ions penetration. The influence of bituminous addition on the concrete permeability was evaluated on the ground of long-term monitoring of resistivity development of the material subjected to cyclic wetting and drying.

\section{Experimental investigation}

\subsection{Materials and specimens preparation}

The tests were carried out for fine-grained concrete. Two types of Portland cement recommended for bridges and highway structures were used: the sulphate resistant CEM I 42,5 HSR NA (C1), and moderate sulphate resistant CEM I 42,5 MSR NA (C2). The mineral compositions of cements used are presented in Table 1.

Table 1. Mineral compositions of cements

\begin{tabular}{c|c|c|c|c|c|c}
\hline \multirow{2}{*}{ Cement } & \multicolumn{6}{|c}{ Content in mass, \% } \\
\cline { 2 - 7 } & $\mathrm{C}_{3} \mathrm{~S}$ & $\mathrm{C}_{2} \mathrm{~S}$ & $\mathrm{C}_{3} \mathrm{~A}$ & $\mathrm{C}_{4} \mathrm{AF}$ & $\mathrm{Na}_{2} \mathrm{O}_{\mathrm{eq}}$ & $\mathrm{SO}_{3}$ \\
\hline $\begin{array}{c}\text { CEM I } \\
\text { 42,5 HSR } \\
\text { NA (C1) }\end{array}$ & 61,3 & 14,6 & 2,1 & 15,6 & 0,49 & 2,33 \\
\hline $\begin{array}{c}\text { CEM I } \\
\text { 42,5 MSR } \\
\text { NA (C2) }\end{array}$ & 59,7 & 15,5 & 7,8 & 10,5 & 0,54 & 1,79 \\
\hline
\end{tabular}

All concrete mixes tested were characterised by identically plastic consistence, which demanded the correction of water amount each time. The cement content in tested concretes was constant $\left(450 \mathrm{~kg} / \mathrm{m}^{3}\right)$.

The bituminous paste - industrial asphalt solution in high-boiling organic solvent - was a modifying com- ponent. The addition of bituminous paste was included in the batch of concrete by suitable reduction of aggregate amounts. The fine aggregate used was quartz sand with a maximum diameter of $2 \mathrm{~mm}$, the coarse aggregate - basalt grit with maximum diameter of $8 \mathrm{~mm}$.

The tests were carried out with specimens prepared of mixtures with two different values of addition content as well as with unmodified control specimens. The mass ratio of the bituminous paste to cement $(p / c)$, determined on the ground of previous test results, described in [7, 8], was 0,$11 ; 0,13$ for cement $\mathrm{C} 1$ and $0,095,0,11$ for cement $\mathrm{C} 2$. A water-cement ratio $(\mathrm{w} / \mathrm{c})$ in the tested concretes ranged from 0,355 to 0,395 (dependably on the bituminous paste content).

The specimens of $100 \times 100 \times 50 \mathrm{~mm}$ with pairs of stainless steel electrodes, with active surface of $10 \mathrm{~cm}^{2}$, embedded in hardened concrete, were used for evaluating electric resistivity. The thickness of concrete covering electrodes was $2 \mathrm{~cm}$. Test specimens were prepared using vibration table. They were stored $24 \mathrm{~h}$ in the moulds at $95 \%(\mathrm{RH})$ and $18{ }^{\circ} \mathrm{C}$ and, after demoulding, kept 27 days in a climatic chamber at $95 \%(\mathrm{RH})$ and $18{ }^{\circ} \mathrm{C}$.

The test results of basic properties of concretes are summarised in Table 2 . The water absorbability and capillary suction of concretes were determined by the standard PN-85/B-04500 [9] and the compressive strength by PN-EN 12390-3: 2002 [10]. The total porosity value was calculated considering bulk density as well as specific density of concrete. The introduction of asphalt addition (in the range of $p / c$ values) results in a significant decrease of water absorption and capillary suction of $3 \% \mathrm{NaCl}$ solution as well as the decrease of compressive strength, but the compressive strength of modified concrete is within the range of ordinary structural concrete.

\subsection{Exposure test and monitoring}

The electrical resistivity development was monitored for concrete samples exposed in cyclic wetting and drying conditions. The samples were wetted in $3 \% \mathrm{NaCl}$ solution and comparatively in water.

Table 2. Selected properties of concrete tested

\begin{tabular}{c|c|c|c|c|c|c|c}
\hline \multirow{2}{*}{$\begin{array}{c}\text { Type of } \\
\text { cement }\end{array}$} & $p / c$ & $w / c$ & $\begin{array}{c}\text { Water } \\
\text { absorbability, } \\
\%\end{array}$ & $\begin{array}{c}\text { Capillary suction } \\
\text { of } 3 \% \text { NaCl, } \\
\mathrm{kg} / \mathrm{m}^{2}\end{array}$ & $\begin{array}{c}\text { Total } \\
\text { porosity, } \\
\%\end{array}$ & \multicolumn{2}{|c}{$\begin{array}{c}\text { Compressive strength, } \\
\text { MPa }\end{array}$} \\
\hline \multirow{5}{*}{$\mathbf{C 1}$} & 0,0 & 0,395 & 4,28 & 1,96 & 12,88 & 61,5 & 69,2 \\
\cline { 2 - 9 } & 0,11 & 0,370 & 1,87 & 0,59 & 14,15 & 43,1 & 58,8 \\
\hline \multirow{3}{*}{$\mathbf{C 2}$} & 0,13 & 0,355 & 1,91 & 0,56 & 14,09 & 35,6 & 41,2 \\
\cline { 2 - 9 } & 0,0 & 0,395 & 4,33 & 1,86 & 12,69 & 69,4 & 74,9 \\
\hline & 0,095 & 0,380 & 1,92 & 0,68 & 14,23 & 51,3 & 63,1 \\
\hline
\end{tabular}


After 28 days of curing the concrete samples were exposed to cyclic wetting and drying, permitting moisture movement through concrete pores. The wetting period in $3 \% \mathrm{NaCl}$ solution or in water was 5 days, but the time of drying, at $40 \% \mathrm{RH}$ and $18{ }^{\circ} \mathrm{C}$, was 7 days. During wetting, the samples were partially (to $4 / 5$ of their depth) submerged in solution, which could intensify the chlorides migration caused by absorption and capillary suction.

The resistance was measured between pairs of electrodes using $1 \div 2 \mathrm{kHz}$ AC. The resistivity was calculated considering the effective area of the steel electrodes and their separation distance. The first measurement was carried out after 28 days of curing.

\section{Test results}

The development of electric resistivity of concretes wetted in water was presented in Fig 1, and the concretes wetted in $\mathrm{NaCl}$ solution in Fig 2.

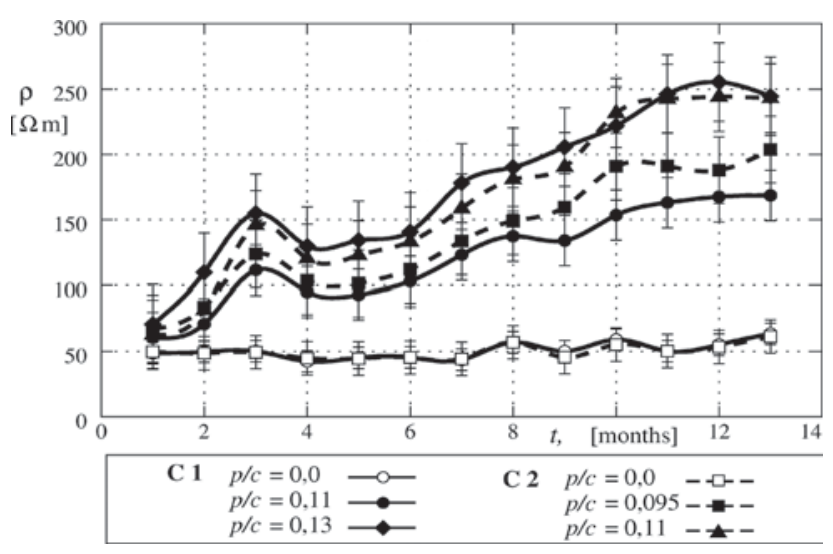

Fig 1. Electric resistivity of concrete $r$ wetted in water vs time of exposure $t$ as well as $p / c$ value (vertical bars represent the range of accuracy)

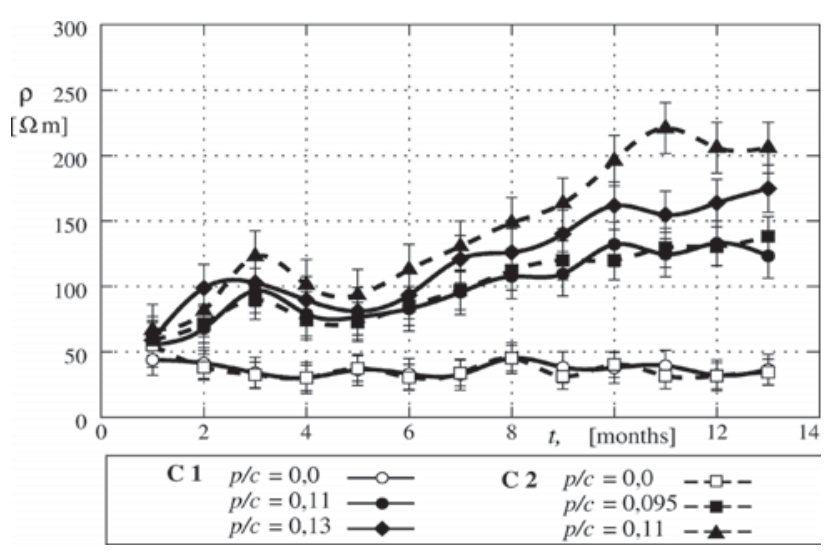

Fig 2. Electric resistivity of concrete $\mathrm{r}$ wetted in $\mathrm{NaCl}$ solution vs time of exposure $t$ as well as $p / c$ value
The effects of time of exposure $t$ (factor A), $p / c$ value (factor $\mathrm{B}$ ), type of cement (factor $\mathrm{C}$ - qualitative) and $\mathrm{NaCl}$ concentration in solution (factor $\mathrm{D}$ ) on the electric resistivity of concrete $\mathrm{r}$ (variable $Y$ ) have been studied using the method of variance analysis. In this analysis both the basic effects and the higher order interactions were analysed. For statistical interpretation of regression and analysis of variance it was assumed that the data was normally distributed.

Before the proper analysis, the Cochran's G test was used as a homogeneity test. The results of every month resistivity measurements of 6 concrete mixes were taken into account. The test showed that for 156 means and the degrees of freedom $d f=2$, the calculated value equals

$G_{i j k \max }=S_{i j k \max }^{2} / \Sigma S_{i j k}^{2}=941,66 / 16708.18=0,0564$,

for level of significance $\alpha=0,05$ is less than $G_{0,05,2,156}=$ 0,0632 [11], thus the compared variances are homogeneous and the test results reproducible.

The variance analysis was carried out in compliance with the procedure given in [11]. The results are given in Table 3.

The F-Fisher test [11] was used to verify the hypothesis that $\mathrm{A}, \mathrm{B}, \mathrm{C}$ and $\mathrm{D}$ factors had a significant effect on concrete resistivity development. The influence of the individual factor or the interaction is recognised as significant if

$$
F_{\text {exper }}>F_{t a b}=F_{\alpha, f_{1}, f_{2}},
$$

where $\alpha=0,05-$ level of significance, $f_{1}$, and $f_{2}-$ degrees of freedom.

As a result of the variance analysis, it has been found that individual factors and the first-order interactions as well as the second-order interaction have a significant effect on the resistivity development. Only the interaction of $\mathrm{A}, \mathrm{C}$ and $\mathrm{D}$ factors as well as the interaction of A, B, C and D have statistically insignificant effect. The percentage fraction of factors and interactions influence h was calculated too (Table 3).

For predicting the resistivity of concrete subjected to cyclic wetting and drying, a mathematical model describing the resistivity changes (function $\hat{Y}$ ) in dependence on selected factors was developed. Only the effect of the quantitative factors was taken into account: $p / c$ ratio - factor $X_{1}$, time of exposure $t$ (months) - factor $X_{2}$ and $\mathrm{NaCl}$ concentration in solution - factor $X_{3}$, separately for each cement.

For mathematical model elaboration the following factor's levels, significant for practice, were selected:

- factor $X_{1}: 0,11 ; 0,13$ (for cement C1);0,095; 0,11 (for cement $\mathrm{C} 2$ ),

- factor $X_{2}: 0,3,6,9,12$ months of exposure,

- factor $X_{3}: 0,3 \%$.

As a function describing the resistivity development due to cyclic wetting and drying, the orthogonal polynomial was assumed. The values of regression equation coefficients were determined using the least-squares method. 
Table 3. Analysis of variance results

\begin{tabular}{c|c|c|c|c|c|c}
\hline Source of variation & Sums of squares & Degrees of freedom & Mean squares & $F_{\text {exper }}$ & $F_{\text {tab }}$ & $\begin{array}{c}\eta \\
(\%)\end{array}$ \\
\hline Factor A & 352948,8 & 12 & 29412,4 & 279,51 & 1,79 & 21,19 \\
\hline Factor B & 932931,0 & 2 & 466465,5 & 4432,84 & 3,02 & 56,02 \\
\hline A and B & 191508,2 & 24 & 7979,5 & 75,83 & 1,58 & 11,50 \\
\hline Factor C & 2796,4 & 1 & 2796,4 & 26,57 & 3,88 & 0,17 \\
\hline A and C & 3329,8 & 12 & 277,5 & 2,64 & 1,79 & 0,20 \\
\hline B and C & 2045,9 & 2 & 1022,9 & 9,72 & 3,02 & 0,12 \\
\hline A and B and C & 5044,6 & 24 & 210,2 & 2,00 & 1,58 & 0,30 \\
\hline Factor D & 91446,7 & 1 & 91446,7 & 869,02 & 3,88 & 5,49 \\
\hline A and D & 17268,5 & 12 & 1439,0 & 13,68 & 1,79 & 1,04 \\
\hline B and D & 13165,5 & 2 & 6582,7 & 62,56 & 3,02 & 0,79 \\
\hline A and B and D & 4302,8 & 24 & 179,3 & 1,70 & 1,58 & 0,26 \\
\hline C and D & 775,0 & 1 & 775,0 & 7,36 & 3,88 & 0,05 \\
\hline A and C and D & 636,8 & 12 & 55,1 & 0,50 & 1,79 & 0,04 \\
\hline B and C and D & 11349,8 & 2 & 5674,9 & 53,93 & 3,02 & 0,68 \\
\hline A, B, C and D & 2996,5 & 24 & 124,8 & 1,19 & 1,58 & 0,18 \\
\hline Error & 32831,6 & 312 & 107,1 & - & - & 1,97 \\
\hline
\end{tabular}

The calculations were conducted by the Data Analysis Programs | STAT [12].

The relationship for the cement $\mathrm{C} 1$ concrete has been obtained as:

$$
\begin{gathered}
\hat{Y}_{1}=66,35-31,81 X_{2}+371,3 X_{1} X_{2}+ \\
5,208 X_{2} X_{3}-57,97 X_{1} X_{2} X_{3},
\end{gathered}
$$

for the cement $\mathrm{C} 2$ concrete:

$$
\begin{gathered}
\hat{Y}_{2}=64,67-12,01 X_{2}+256,3 X_{1} X_{2}- \\
7,728 X_{2} X_{3}+58,86 X_{1} X_{2} X_{3} .
\end{gathered}
$$

The adequacy of the relationships obtained was tested using the F-Fisher test [11]. The experimental $F$-value for concretes made with cement $\mathrm{C} 1$ is equal to $F_{\text {exper } 1}=1,90$ and for concretes made with cement $\mathrm{C} 2-$ $F_{\text {exper } 2}=1,88$. The critical $F$-value, for $\alpha=0,05$ and degrees of freedom $f_{1}=N-d^{*}=20-5=15$ and $f_{2}=N(n-1)=20(3-1)=40$, equals $F_{\text {crit }}=1,96$. The degrees of freedom were calculated considering: $N-$ number of variances $-20, d^{*}$ - number of relationship coefficients -5 and $n-$ number of replicates -3 . The experimental values $F_{\text {exper }}$ are less than the critical value $F_{c r i t}$ thus the analysis indicates a good fit to the relationships obtained.

\section{Interpretation}

In order to make the interpretation results easier, the relationships (3) and (4) were presented graphically in the form of isolines (Figs 3 and 4).
The analysis of dependency $r=f(p / c, t)$ for cement $\mathrm{C} 1$ concretes, stored in water as well as in $3 \%$ $\mathrm{NaCl}$ solution, showed beneficial influence of the exposure time and the bituminous addition on the resistivity. It means that with an increase of $X_{1}$ and $X_{2}$ factors value, the value of $\hat{Y}$ increases. The increase of resistivity amounts on average:

- with change in $X_{1}$ value from 0,11 to $0,13 \sim 45 \Omega \mathrm{m}$, it means about $37 \%$ for concrete samples wetted in water and $\sim 24 \Omega \mathrm{m}$, it means about $24 \%$ for concrete samples wetted in $\mathrm{NaCl}$ solution;

- with change in $X_{2}$ value from 0 to 12 months $\sim 153 \Omega \mathrm{m}(\sim 230 \%)$ for water storage and $\sim 90 \Omega \mathrm{m}$ $(\sim 135 \%)$ for $\mathrm{NaCl}$ solution storage.

The analysis of the selected factors influence on the resistivity of cement $\mathrm{C} 2$ concretes showed that the qualitative effect is the same as for cement $\mathrm{C} 1$ concretes. The difference is in a quantitative effect. The increase in resistivity, in case of cement $\mathrm{C} 2$ concretes, amounts to on the average:

- with the change in $X_{1}$ value from 0,095 to 0,11 $\sim 23 \Omega \mathrm{m}(\sim 17 \%)$ for water storage and $\sim 39 \Omega \mathrm{m}$ $(\sim 39 \%)$ for $\mathrm{NaCl}$ solution storage;

- with the change in $X_{2}$ value from 0 to 12 months $\sim 171 \Omega \mathrm{m}(\sim 265 \%)$ for water storage and $\sim 110 \Omega \mathrm{m}$ $(\sim 170 \%)$ for $\mathrm{NaCl}$ solution storage.

The reason for the resistivity increase may be the tightening of material structure during the experiment, caused by prolongation of hydration process in the presence of bituminous addition, which was shown in previous investigations [4]. Moreover, the tightening of concrete through blocking the pores of material with a bituminous addition is conducive to the increase in resistivity. 
a)

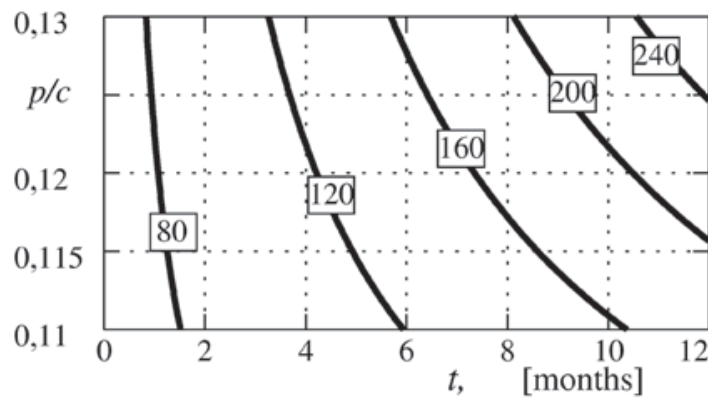

b)

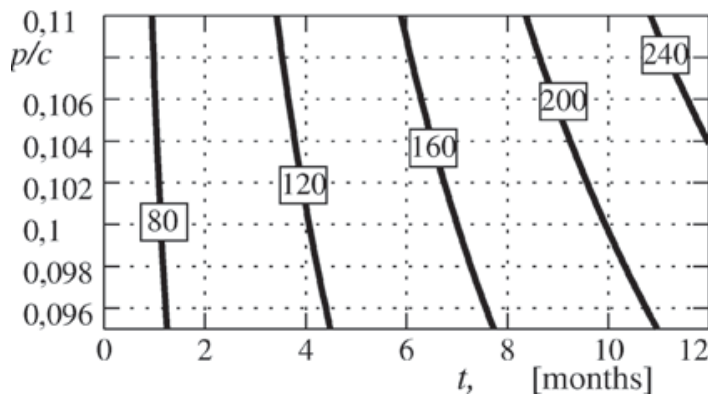

Fig 3. Isolines of resistivity of concretes wetted in water $\hat{Y}(\rho, \Omega m)$ vs $X_{1}(\mathrm{p} / \mathrm{c})$ and time of exposure $\mathrm{X}_{2}(t$, months); a) for cement $\mathrm{C} 1$ concretes; b) for cement $\mathrm{C} 2$ concretes

There is not a significant difference in the resistivity of concretes made of cement $\mathrm{C} 1$ and cement $\mathrm{C} 2$, stored in water as well as in $\mathrm{NaCl}$ solution. The percentage fraction $\eta$ (Table 3 ) of factor C-type of cement influence, which is about $0,17 \%$, indicates that sort of cement has any practical effect on the resistivity.

The comparison of the resistivity values of concretes, wetted in water and in salt solution, showed that the resistivity, independently of the cement used, increases more slowly in case of samples stored in $\mathrm{NaCl}$ solution. This can be explained by accumulation, in the pore space, some amount of $\mathrm{NaCl}$ crystals, which causes the increase in sorptive humidity of porous materials. The increase in humidity is conducive to formation of the pore liquid, what, in effect, causes the decrease of resistivity. This conclusion is confirmed by the results of variance analysis. The percentage fraction of factor D (environment of exposure) influence is about 5,5\%.

In case of concretes without a bituminous addition, stored in water, the electrical resistivity did not change during the experiment, keeping up the value reached after 28 days of curing $\sim 50 \mathrm{Wm}$. After 12 months of cyclic wetting in $\mathrm{NaCl}$ solution the resistivity of unmodified concrete reached the values reduced about $35 \%$ in comparison to the resistivity value after 28 days of curing. a)

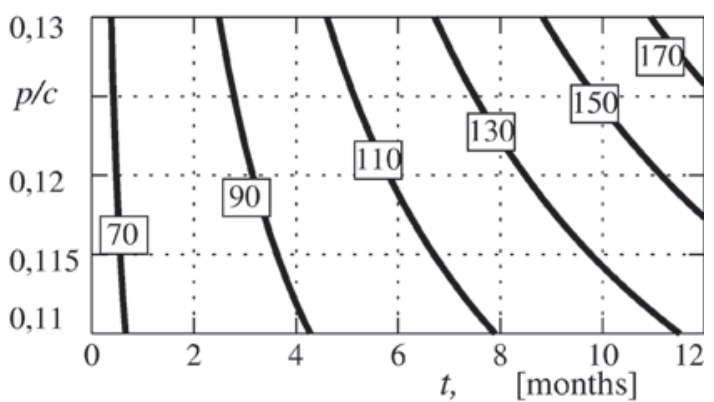

b)

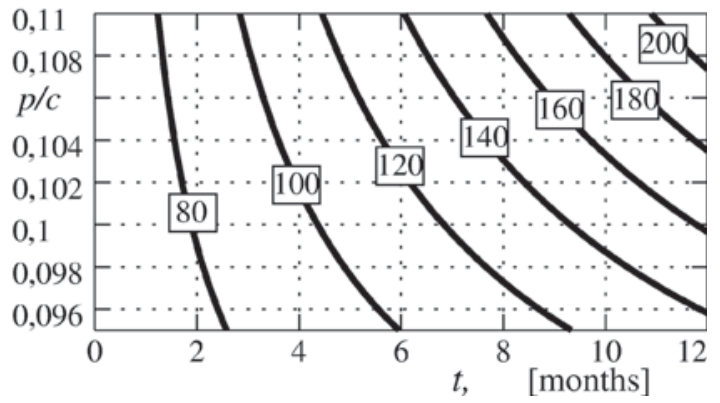

Fig 4. Isolines of resistivity of concretes wetted in $\mathrm{NaCl}$ solution $\hat{Y}(\rho, \Omega \mathrm{m})$ vs $X_{1}(p / c)$ and time of exposure $X_{2}$ $(t$, months); a) for cement $\mathrm{C} 1$ concretes; b) for cement $\mathrm{C} 2$ concretes

\section{Conclusions}

1. The concretes, made with Portland cements recommended for bridges and highway structures, containing bituminous addition, showed a significantly higher resistivity than the control plain concrete. After 12 months of monitoring, the resistivity of modified concretes was $\sim 5$ times greater than of plain concretes, wetted in water as well as in salt solution.

2. The factors, such as time of exposure, the bituminous addition content and the sort of exposure environment (water or salt solution) have significant effect on concrete resistivity. The $p / c$ value and the time of exposition in cyclic wetting and drying conditions have the greatest influence expressed in the percentage fraction, $56 \%$ and $21 \%$ respectively. The influence of cement type was practically insignificant.

\section{Acknowledgement}

This paper was elaborated with the financial support of State Committee for Scientific Research; project number $\mathrm{W} / \mathrm{IIB} / 6 / 03$.

\section{References}

1. Neville, A. Chloride attack of reinforced concrete: an overview. Materials and Structures, Vol 28, 1995, p. 63-70. 
2. Hong, K.; Hooton, R. D. Effect of cyclic chloride exposure on penetration of concrete cover. Cement and Concrete Research, Vol 29, 1999, p. 1379-1386.

3. Ramachandran, V. S. Concrete admixtures handbook. Properties, Science and Technology, Noyes Publications, Park Ridge, New Jersey, 1984.

4. Wieczorek, G.; Kosior-Kazberuk, M. Asphalt modified concretes and mortars. In: Science of Cement and Concrete. Kurdowski, W.; Gawlicki, M. (Eds.), Kraków 2001, p. $315-330$.

5. Polder, R. B.; Peelen, W. H. A. Characterisation of chloride transport and reinforcement corrosion in concrete under cyclic wetting and drying by electrical resistivity. $\mathrm{Ce}$ ment and Concrete Composites, Vol 24, 2002, p. 427.

6. Živica, V. Utilisation of electrical resistance method for the evaluation of the state of steel reinforcement in concrete and the rate of its corrosion. Construction and Building Materials, Vol 14, 2000, p. 351-358.
7. Kosior-Kazberuk, M. Effect of concrete mix modification with asphalt on the selected properties of concrete. In: Proc of $4^{\text {th }}$ International $\mathrm{Ph} \mathrm{D}$ Symposium in Civil Engineering, Springer VDI Verlag, Monachium, 2002, p. 332-337.

8. Kosior-Kazberuk, M.; Jezierski, W. Surface scaling resistance of concrete modified with bituminous addition. Journal of Civil Engineering and Management, Vol X, No 1, 2004, p. 25-30.

9. PN-85/B-04500 Mortars. Physical and mechanical tests.

10. PN-EN 12390-3: 2002 Testing hardened concrete - Part 3: Compressive strength of test specimens.

11. Hartman, K.; Lecki, E.; Schäfer, W. Statistische Versuchplanung und Auswertung in der Stoffwirtschaft. Leipzig, 1977.

12. Perlman, G. The STAT Handbook. Data analysis programs on UNIX and MSDOS, 1986.

\section{BETONO ATSPARUMO CHLORO JONŲ SKVARBAI İVERTINIMAS STEBINT ELEKTRINĖS VARŽOS KITIMĄ}

\section{Kosior-Kazberuk, W. Jezierski}

Santrauka

Betono ir gelžbetonio atžvilgiu chloro jonai yra agresyvus veiksnys, skatinantis armatūrinio plieno ir betono koroziją. Pateikiami bituminio priedo betone itakos tyrimų rezultatai chloro jonų skvarbai jame. Siekiant įvertinti betono pasipriešinimą tokiems difuzijos procesams, remtasi eksperimentiniais medžiagos elektrinès varžos matavimo rezultatais. Taikant statistinius tyrimų metodus, atlikta rezultatų dispersinė ir regresinė analizè, aiškinantis betono elektrinės varžos kitimo tendencijas priklausomai nuo panaudoto cemento rūšies, bituminio priedo kiekio, $\mathrm{NaCl}$ vandeninio tirpalo, skirto bandiniams i̇mirkyti, koncentracijos, ir agresyvaus priedo poveikio trukmès. Statistinè analizè patvirtino gana teigiamą ir naudingą bituminio priedo betone poveikio itaką ribojant chloro druskų tirpalų skvarbą ì betoną.

Raktažodžiai: betonas, chloro jonai, elektrinė varža, struktūrinė apsauga, bituminis priedas, dispersinè analizė, regresija.

Marta KOSIOR-KAZBERUK works at the Chair of Concrete and Masonry Structures, Dept of Civil Engineering and Environmental Engineering at the Bialystok Technical University (Poland), where she received her PhD degree. Member of Polish Ceramics Society. Her research interests include durability of building materials and structures with emphasis on diagnostic methods.

Walery JEZIERSKI. Professor in the Chair of Building Fundamentals and Physics, Department of Civil Engineering and Environmental Engineering at the Bialystok Technical University, Poland. Associate member of International Engineering Academy (Moscow) and a member of Scientific Committee of Polish Civil Engineers and Technicians Association. His research interests include physics, reliability in building industry and properties of building materials. 